\title{
Past, present and future of the fish community of Lake Orta (Italy), one of the world's largest acidified lakes
}

\author{
Pietro VOLTA,${ }^{1 *}$ Norman D. YAN, ${ }^{2}$ John M. GUNN ${ }^{3}$ \\ ${ }^{1}$ National Research Council, Institute of Ecosystem Study, Largo Tonolli 50, 28922 Verbania, Italy; ${ }^{2}$ Biology Department, York University, \\ Toronto, Ontario, Canada M3J 1P3; ${ }^{3}$ Vale Living with Lakes Centre, Laurentian University, Sudbury, Ontario, Canada P3E 2C6 \\ *Corresponding author: p.volta@ise.cnr.it
}

\begin{abstract}
Since 1926, the fishes in Lake Orta, one of Italy's deepest natural lakes, were heavily damaged by profundal hypoxia and acidification linked to oxidation of ammonia from industrial effluents and by industrial metal pollution. Of the original 28 fish species, only perch survived the lake's contamination. Recently, the water quality of the lake has been largely restored by reductions in pollutant inputs, and a massive liming intervention. These interventions restored fish habitat, but it is unclear whether the recent fish reintroductions were successful, and the present status of the fish community is unknown. Here we reviewed the history of the Lake Orta fish assemblage. Using an extensive 2014 sampling campaign, we compared the present fish community to both its pre-pollution composition and to the assemblages of nearby un-polluted, but otherwise similar lakes, Lake Mergozzo and Lake Maggiore. While nearshore fish density now appears normal in lake Orta, the open water community remains impoverished both in numbers and in species. Epilimnetic and hypolimnetic benthic nets were dominated by perch and roach in all the three lakes, but the catch of pelagic nets differed among lakes. Perch (Perca fluviatilis), rudd (Scardinius erythrophthalmus) and brown trout (Salmo trutta) dominated in Lake Orta while shad (Alosa fallax lacustris) and coregonids (Coregonus spp.) were dominant in the open waters of the other two lakes, but missing from Lake Orta. Many fully or partially migratory species, including marble trout (Salmo trutta marmoratus), eel (Anguilla Anguilla) and barbel (Barbus plebejus) were also missing from Lake Orta, a consequence of their initial extirpation and blocked re-colonization routes along the River Strona. In comparison with both pre-pollution and contemporary reference data, the fish community of Lake Orta has not been rehabilitated. The recovery of the littoral community is complete, but cold water species such as burbot (Lota lota), Arctic charr (Salvelinus alpinus) and bullhead (Cottus gobio) are still lacking, as are the pelagic zooplanktivores European whitefish (Coregonus lavaretus) and shad, which dominate offshore communities in the reference lakes, as they did a century ago in Lake Orta. To propose priorities for fish community rehabilitation in Lake Orta, we categorized the conservation, ecological and fishing values of each missing fish species in the lake, and evaluated the cost and probability of success of the needed intervention for each species. This analysis indicated that rehabilitation of shad and European whitefish should receive highest priority.
\end{abstract}

Key words: Lake acidification; lake restoration; copper pollution; deep lakes; fish species.

Received: August 2015. Accepted: November 2015.

\section{INTRODUCTION}

Lakes and their fish communities are affected by natural and anthropogenic events occurring both within and beyond their boundaries. These events can include disturbances such as overharvesting, habitat degradation, and climate change (Hutchings and Festa-Bianchet, 2009), but among anthropogenic pressures that have damaged lakes in northern hemisphere, acidification of waters has been among the most significant. While acid rain, linked to atmospheric emissions of NOx and especially to $\mathrm{SO}_{2}$, has led to the acidification of the largest number of lakes (Galloway 2001), extensively damaging fish, in northern $\mathrm{Eu}-$ rope (Henriksen et al. 1989) and North America (Likens et al. 1979), it has not been the only cause of lake acidification. Two other causes of acidification are acid mine drainage or effluents (Pain et al. 1998), and the oxidation of anthropogenic ammonia, either of fertilizer origin, or, as is the case for Lake Orta in Italy, from liquid industrial wastes (Schuurkes and Mosello 1988). However, whilst almost all previous studies of acidified lakes have been of northern, oligotrophic waters with simple fish communities dominated by salmonids such as brown trout that have been impacted by acid rain, we focused on Lake Orta with its much more complex fish community, and differing source of acidity.

With a surface area of 1814 ha, a max depth of $143 \mathrm{~m}$, and a volume of $1.29 \mathrm{~km}^{3}$, Lake Orta, is among the largest and deepest lakes in Italy, and a very important lake for tourism. However, Lake Orta also has a history of industrial pollution, and, given its volume, it can be considered one of the largest lakes in the world to have undergone acidification. Beginning in 1926, the lake was polluted by ammonium and copper sulphate from a rayon factory. So serious was the algicidal effect of copper salts, that the whole food web of the lake, including its plankton, ben- 
thos and fish fauna, was seriously damaged within a few years (Monti, 1930). The situation then worsened in three ways. In the 1950s, $\mathrm{Cu}, \mathrm{Cr}, \mathrm{Ni}$ and $\mathrm{Al}$ discharges from metal plating and manufacturing industries in the watershed contaminated the lake with additional metals, and the oxidation of ammonia both consumed profundal oxygen and inexorably acidified the lake. Indeed the $\mathrm{pH}$ of the lake had fallen to an annual minimum of 3.9 by 1985 . The fish fauna, the biotic component most visible to the public, was heavily damaged and any potential recovery was compromised by the construction of impassable dams along the River Strona, the lake's outlet, dams which prevented any possible natural recolonization from the neighbouring Lake Maggiore.

Recently the water quality in the lake has improved dramatically both because of reduced pollutant inputs and a massive liming intervention. The industrial discharges of ammonia dropped from 2000 tons $\mathrm{yr}^{-1}$ in the 1940s to less than 30 tons $\mathrm{yr}^{-1}$ in the $1980 \mathrm{~s}$, while copper inputs were decreased from $\sim 80$ tons $\mathrm{yr}^{-1}$ in 1940 s to $\sim 5$ tons $\mathrm{y}$ ${ }^{1}$ in the 1980s. In addition, the lake was limed in 19891990, accelerating water quality recovery (Calderoni et al., 1992; Bonacina 2001). These restorative efforts rapidly repaired the chemical and physical conditions of the lake (Calderoni and Tartari, 2001; Bonacina, 2001), creating improved habitat conditions for biota (Rogora et al., 2016). However, the biota of the lake has responded more slowly, and have still not fully rehabilitated (Bonacina, 2001; Piscia et al., 2016). For example, after liming, there were several attempts to reintroduce various fish species, including cyprinids, centrarchids and salmonids from the neighbouring Lake Maggiore and other adjacent water bodies. At present there is some anecdotal evidence from local anglers, that Lake Orta does have abundant fish populations, but because of the absence of quantitative and extensive monitoring programs of the fish community since liming, we lack information both on which if any introduced species were successful, and of the present status of the fish community. Here, we have three objectives: i) to present the history of the Lake Orta fish assemblages; ii) to evaluate the present status of the lake's fish populations based on an extensive fish sampling campaign from 2014, in comparison with the neighbouring reference lakes of similar typology (Volta et al., 2011b), Lake Maggiore and Lake Mergozzo, and iii) to use the available data to set priorities for additional restoration efforts for the fish community. We hypothesized that: i) because of the severity of past pollution and the interruption of primary migratory routes, the present fish community would be comprised only of the species that have been recently introduced, and those pollution-tolerant species that survived that lake's contaminated past; ii) the current dominant species would be those with the most flexible life-history traits, such as percids and some cyprinids, fish with ontogenetic diet shifts/omnivory, flexibility in habitat use and earlier spawning period; and iii) truly pelagic zooplanktivorous species would be absent from the lake as they were never re-introduced, and, for this reason, the lake's open waters would be relatively fishless compared to the two neighbouring lakes, Lake Maggiore and Lake Mergozzo, that did not suffer Lake Orta's contamination. Should hypothesis 3 be supported by our new data, we would suggest that this open water habitat, could be a target for the re-introduction of pelagic species, a repeat of a previous late $19^{\text {th }}$ century introduction.

\section{METHODS}

\section{Historical data collection and elaboration}

To address our first objective, we assembled and analysed the available literature data on fish extracted from the historical library of the CNR-Institute of Ecosystem Study. Most of the documents were from the period 1850-1950 and included both scientific papers and technical reports from universities and research institutions. The data assembled from this historical analysis were checked for species identification against those from recent publications (Gandolfi et al., 1991; Zerunian, 2004) which the Ministry of the Environment recognizes as the official reference publications on the Italian fish fauna, tabulated in Gandolfi et al. (1991).

\section{Fish sampling and data analysis}

To address our second objective, both benthic and mesopelagic survey gill nets were deployed to sample fish populations (Appelberg et al., 1995; CEN, 2005; Smejkal et al., 2015). Each benthic net was $40 \mathrm{~m}$ long and $1.5 \mathrm{~m}$ high and composed of sixteen panels with mesh sizes ranging from $5.5 \mathrm{~mm}$ to $135 \mathrm{~mm}$. Eighty benthic gill nets were distributed randomly within different depth strata (0 to 2.9 m, 3.0 to $5.9 \mathrm{~m}, 6.0$ to $11.9 \mathrm{~m}, 12.0$ to $19.9 \mathrm{~m}, 20.0 \mathrm{~m}$ to $34.9 \mathrm{~m}, 35.0$ to $49.9 \mathrm{~m}$, and deeper than $50.0 \mathrm{~m}$ ). Pelagic nets were composed by a set of 10 gillnets linked together with a length of $27.5 \mathrm{~m}$ each and height of $6 \mathrm{~m}$ and 11 panels (with a mesh size from $8 \mathrm{~mm}$ to $55 \mathrm{~mm}$, knot to knot). An additional four nets (with additional mesh size of 70 $\mathrm{m}, 90 \mathrm{~m}, 110 \mathrm{~m}$ and $135 \mathrm{~mm}$ knot to knot, and a length of 40 meters and height of 6 meters each) were also used for a total length of mesopelagic net set of $435 \mathrm{~m}$. Mesopelagic net sets were set at the deepest point of the lake. Mesopelagic nets were set every $10 \mathrm{~m}$ from surface down to $50 \mathrm{~m}$. Hence, five depth strata were investigated.

Fish were sampled between 1 July 2014 and 10 July 2014. Surface water temperature was around $26^{\circ} \mathrm{C}$ and the lake was stratified during the sampling period (Tab. 1). Nets were set at dusk between 18.00 and $19.00 \mathrm{~h}$ and lifted the following morning between 07.00 and $08.00 \mathrm{~h}$. Captured fish were measured (total length to nearest $0.1 \mathrm{~cm}, \mathrm{~L}_{\mathrm{T}}$ ), 
weighed (fresh total body mass to nearest $0.01 \mathrm{~g}, \mathrm{~W}_{\mathrm{T}}$ ) and sexed (female, male, indeterminable) by examination of gonads. Ten scales from a subsample of fish of each species were taken and subsequently used for age determination.

The distribution of fish in the littoral area (depth $\max =1.5 \mathrm{~m}$ ) was further evaluated by electrofishing from a boat according to the National Italian fish sampling protocol (ISPRA, 2014). The electrofishing device was a builtin-frame EL64GII (Scubla Acquaculture, 7000 W, 600 V, DC current) set up with a copper cathode (width $2.5 \mathrm{~cm}$, length $300 \mathrm{~cm}$ ) and with a steel ring anode (thickness 0.8 $\mathrm{cm}$; diameter $50 \mathrm{~cm}$ ). The Point Abundance Sampling Electrofishing (PASE) method (Copp and Garner, 1995) was used, during which the anode was dipped for 20 seconds at each sampling point. A total of 102 points were sampled by electrofishing in the littoral zone. The stunned fish were measured (total length $\mathrm{L}_{\mathrm{T}}$ ); rarer species were also weighed $\left(\mathrm{W}_{\mathrm{T}}\right)$ and scales were taken for age determination.

Catch per unit effort (CPUE) for nets was assessed with respect to net area and calculated as biomass per unit effort (BPUE, $\mathrm{g} \mathrm{net}^{-1}$ ) and numbers per unit effort (NPUE, individuals net $\left.{ }^{-1}\right)$. CPUE for electrofishing was calculated as NPUE (individuals $\mathrm{dip}^{-1}$ ). Error was expressed as standard deviation.

\section{Setting priorities for fish community restoration}

For objective 3, we compared the presence and relative abundance of fish in the lake in 2014 with the historical data we had summarized, and we also compared the 2014 Lake Orta fish assemblages with those of the nonimpacted neighbouring Lake Mergozzo and Lake Maggiore. Species number and composition were numerically compared, and ANOVA on ranks followed by pairwise multiple comparison (Dunn's Method) was run to test differences in BPUE and NPUE of benthic and mesopelagic nets on the whole water column, epilimnion and hypolimnion among the three lakes. Significant differences were set at $\mathrm{P}<0.05$.

Then, considering the calculable value of the missing species, we set priorities for additional restoration efforts for the fish community. We quantified the value of each missing species using four criteria: conservation value, ecological value, fishery value, angling value. The first criterion was based on an assessment of the importance of the species according to European and national legislation on habitat and species conservation (European Council, 1992). The second criterion acknowledged those species considered as main indicators of so-called good ecological status of water bodies, according to the official Italian index used for the ecological status assessment (sensu European Council's directive 2000/60/EC) (Gassner et al., 2014).The third criterion reflected our assessment of the importance of the species for the fishery, a score awarded if the species likely provided significant social and economic value to the fishery prior to its disappearance from the lake in the 1930s. The fourth criteria scored the importance of the species for recreational angling, a factor deemed important for the development of local tourism. Each species was given a score of 0 or 1 for these four criteria, and the scores were summed to provide the final value of the species.

\section{RESULTS}

\section{Lake Orta fish community: 1850-2000}

The earliest information on the Lake Orta fish community is from the late 1800 s. For instance, Rusconi (1892) noted that trout (Salmo trutta lacustris), tench (Tinca tinca), perch (Perca fluviatilis), shad (Alosa fallax lacustris), barbel (Barbus plebejus), riffle dace (Telestes souffia muticellus), pike (Esox lucius) and eel (Anguilla anguilla) were all very abundant in the lake at that time. Pavesi (1896) recorded a fish community of 14 species, with dominant taxa being shad, chub (Leuciscus cephalus), pike and bleak (Alburnus alburnus alborella). However, it is very likely that most of small-bodied species and those of negligible interest for the fisheries, were excluded from these reports. Many less studied or more obscure taxa were most likely present in Lake Orta at that time given they were present in the nearby Lake Maggiore and Lake Mergozzo, and in many other lakes of the Po River Basin (Gandolfi et al., 1991; Volta et al., 2011b) (Tab.1).

In addition to the native species, non-native fish species were introduced into the lake beginning in the middle of $19^{\text {th }}$ century, and the richness of the fish community increased in consequence. The trout Salmo trutta (atlantic lineages) were introduced beginning in the middle of 1800 s, and both arctic charr (Salvelinus alpinus) and European whitefish (Coregonus lavaretus) were introduced in the early 1900s, while pumpkinseed (Lepomis gibbosus) and largemouth bass (Micropterus salmoides) introductions followed shortly thereafter. Thus, just before the beginning of the pollution period, the fish community was composed of 19 species, 14 species of native taxa, and 5 species of well-established introductions (Tab.1).

Lake Orta supported a substantial commercial and recreational fishery until the onset of pollution but documentation of past fish abundances are limited to species of commercial interest. Prior to 1910 , the commercial harvest was composed mainly by perch (130 tons $\left.\mathrm{y}^{-1}\right)$, eel (125 tons $\left.y^{-1}\right)$, trout $\left(120\right.$ tons $\left.y^{-1}\right)$ and shad $\left(135\right.$ tons $\left.y^{-1}\right)$, tench $(84$ tons $\left.\mathrm{y}^{-1}\right)$, pike (55 tons $\left.\mathrm{y}^{-1}\right)$, and after 1910, by shad, char, whitefish, bleak and perch (De Agostini, 1927; Zacchera, 1948; Tonolli, 1957). The annual harvest averaged $36 \mathrm{~kg} / \mathrm{ha}$ w.w., almost double than that of Lake Maggiore.

Pollution destroyed the fishery in the lake. As pollution increased from 1925 to 1950 fish productivity plum- 
meted (Monti, 1930, Baldi, 1949). While only a few qualitative records on fish fauna are available from 19301990 , it is apparent that only perch survived through this period; all other species succumbed (Tab.1) (Giussani, 1990).

Besides the critical physical-chemical situation, the construction of weirs along the River Strona in the 1900s applied additional negative pressure to the lake's fish community. These weirs isolated many fish from their meta-communities, and other species from their spawning sites. As a result, most of the truly migratory species, including the eel and the marble trout, as well as partially migratory rheophilic ones such as pigo (Rutilus pigus) and savetta (Chondrostoma soetta), river dace (Telestes souffia) and barbel (Barbus plebejus) either dramatically decreased or disappeared.
The most recent data on Lake Orta fish assemblage before our sampling have been gathered by the fishing authority of Province of Verbania. These data indicate an increase of the fish species richness from 3 species in 1994 to 13 species in 2000 (Tab.1), but, as with the previous data, quantitative information on abundances are not available. Nonetheless, these data from local anglers, indicate perch and cyprinids, mainly bleak and rudd, are the recent dominants of the fish assemblage.

In summary, before the onset of pollution, the fish fauna of Lake Orta was very diverse including at least 17 species belonging to different functional groups. Fish species diversity and production collapsed as a result of multiple effect of metal pollution, acidification and hypolimnetic hypoxia. Only perch survived. After the chemical recovery, the fish community was, at least partly,

Tab. 1. Species composition of Lake Orta fish community before, during, and after the pollution events.

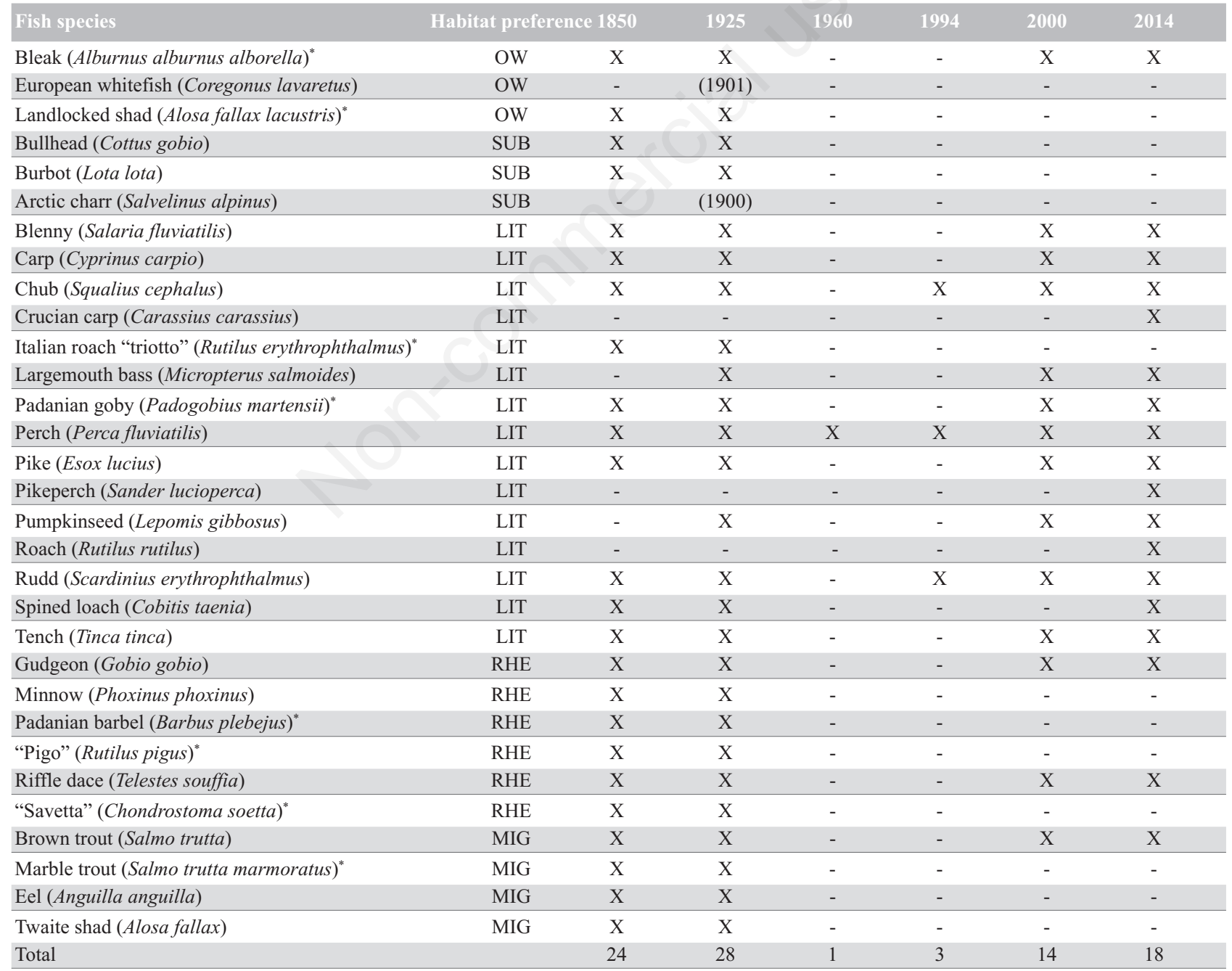

"Endemisms; for non native species, the year of the first introduction is indicated; OW, open waters; SUB, sublittoral waters; LIT, littoral waters; RHE, rheophilic; MIG, migratory. 
rehabilitated by the introduction of cyprinids, centrarchids and salmonids.

\section{Lake Orta fish community: present status}

The current fish community was comprised of pollution-tolerant survivors and recent introductions, but many historical species remain absent (Tab.1). Among the 17 fish species captured, percids and cyprinids were dominant. The most abundant species in the benthic nets indeed were perch $(93.1 \%)$, roach $(5.1 \%)$ and rudd $(1.0 \%)$, whilst, by biomass, benthic nets were dominated by perch (29.3\%), followed by rudd (20.9), carp (17.9\%), roach $(14.2 \%)$ and tench $(4.3 \%)$. In pelagic waters, perch $(85 \%)$ was the most abundant species followed by rudd (7\%) and brown trout $(7 \%)$. Biomass of pelagic nets catches were instead dominated by trout $(47 \%)$ followed by perch $(36 \%)$ and rudd (16\%). Electrofishing catches were dominated by roach $(89.5 \%$ and $61.2 \%$ by numbers and biomass respectively).

The majority of individuals were captured in the upper strata of the water column indicating a presence of only a few fish in the lake's massive hypolimnetic habitat. This is a remarkable difference from the fish assemblages that preceded the pollution period in the lake (Tab.1).

The difference of CPUE between the benthic and mesopelagic nets was quite remarkable. Indeed the BPUE of the benthic gill nets ranged from $0 \mathrm{~g} \mathrm{net}^{-1}$ to $7239 \mathrm{~g}$ net ${ }^{1}$ (mean=1179.6 \pm 2032.9 ) and NPUE from 0 to 1871 ind net $^{-1}$ (mean $\left.=89.9 \pm 253.0\right)$ whilst average BPUE and
NPUE of mesopelagic nets were two to three orders of magnitude lower. BPUE ranged from 0 to $3274 \mathrm{~g} \mathrm{net}^{-1}$ (mean=13.52 \pm 55.5$)$ and NPUE ranged from 0 to 9 ind net $^{-1}$ (mean $\left.=0.07 \pm 0.2\right)$.

The differences in species number and community composition of the three lakes were also quite remarkable. The total number of species both in the benthic nets and in the pelagic nets was much lower in Lake Orta than in the two reference lakes (Tab. 2). Whilst the littoral fish community was relatively similar, the differences were mainly attributable to the lack of pelagic, deep water and migratory species in Lake Orta. Indeed, epilimnetic and hypolimnetic benthic nets were dominated by perch and roach in all three lakes but the catch of mesopelagic nets was very different: on the whole, perch, rudd and trout dominated in Lake Orta whilst shad and coregonids were dominant in the other two lakes (Tab. 2). Among deep and cold water species the burbot, the char and the bullhead were completely missing from Lake Orta compared to the other lakes. As a result (Fig. 1), BPUE and NPUE of hypolimnetic nets of Lake Orta were significantly lower $(p<0.05)$ than those of Lake Maggiore. Also the NPUE of hypolimnetic nets was lower $(p<0.05)$ than Lake Mergozzo giving further evidence to the fact that hypolimnetic waters of Lake Orta have lower fish density than the other two lakes. Finally, likely as a result of the absence of truly pelagic species, both BPUE and NPUE of the pelagic nets were significantly lower in Lake Orta than in Lake Mergozzo and Lake Maggiore $(\mathrm{P}<0.05)$.

Tab. 2. Comparison of the results of fish sampling (number of species and species dominance in benthic and pelagic nets) in Lake Mergozzo, Lake Orta and Lake Maggiore. Major lake characteristics are indicated.

\begin{tabular}{|c|c|c|c|}
\hline Sampling date & $\begin{array}{l}\text { Lake Mergozzo } \\
1-7 / 10 / 2010\end{array}$ & $\begin{array}{l}\text { Lake Orta } \\
1-9 / 7 / 2014\end{array}$ & $\begin{array}{c}\text { Lake Maggiore } \\
1-30 / 7 / 2013\end{array}$ \\
\hline Max. depth (m) & 73 & 143 & 376 \\
\hline Surface area (ha) & 183.0 & 1813.6 & 21000.0 \\
\hline TP mean $\left(\mu \mathrm{g} \mathrm{L}^{-1}\right)$ at winter mixing & 4 & 4 & 12 \\
\hline Thermocline depth $(\mathrm{m})$ at sampling time & 16 & 13 & 13 \\
\hline \multicolumn{4}{|c|}{ Benthic nets } \\
\hline $\begin{array}{l}\text { N. fish species - Epy } \\
\text { Dominant species (number) } \\
\text { Dominant species (biomass) }\end{array}$ & $\begin{array}{l}\quad 23 \\
\text { Roach, perch } \\
\text { Roach, perch }\end{array}$ & $\begin{array}{c}17 \\
\text { Perch, roach } \\
\text { Perch, roach }\end{array}$ & $\begin{array}{l}25 \\
\text { Perch, roach } \\
\text { Perch, roach }\end{array}$ \\
\hline $\begin{array}{l}\text { N. fish species - Hypo } \\
\text { Dominant species (number) } \\
\text { Dominant species (biomass) }\end{array}$ & $\begin{array}{c}8 \\
\text { Perch, roach } \\
\text { Perch, roach }\end{array}$ & $\begin{array}{c}5 \\
\text { Perch, roach } \\
\text { Perch, roach }\end{array}$ & $\begin{array}{l}9 \\
\text { Perch, roach } \\
\text { Perch, roach }\end{array}$ \\
\hline \multicolumn{4}{|c|}{ Pelagic nets } \\
\hline $\begin{array}{l}\text { n. species - Epy } \\
\text { Dominant species (number) } \\
\text { Dominant species (biomass) }\end{array}$ & $\begin{array}{c}3 \\
\text { Bleak, shad } \\
\text { Shad, bleak }\end{array}$ & $\begin{array}{l}\quad 4 \\
\text { Perch, rudd } \\
\text { Perch, rudd }\end{array}$ & $\begin{array}{c}8 \\
\text { Roach, shad } \\
\text { Roach, shad }\end{array}$ \\
\hline $\begin{array}{l}\text { n. specie - Hypo } \\
\text { Dominant species (number) } \\
\text { Dominant species (biomass) }\end{array}$ & $\begin{array}{c}2 \\
\text { European whitefish, shad } \\
\text { European whitefish, shad }\end{array}$ & $\begin{array}{l}1 \\
\text { Perch, trout } \\
\text { Trout, perch }\end{array}$ & $\begin{array}{c}3 \\
\text { Coregonids, shad } \\
\text { Coregonids, shad }\end{array}$ \\
\hline
\end{tabular}


In summary, our data indicate that the Lake Orta fish assemblage is currently dominated by a littoral fish community, whilst both the sublittoral and open water environments show very low fish densities. Despite the water quality recovery of the lake, the contemporary fish assemblage cannot be considered recovered. It differs from the historical community that predates the pollution period, and it also differs in a major way from the neighbouring lakes Maggiore and Mergozzo, that did not lose their fish communities to metal pollution, acidification and deep water hypoxia. The particulars of the ongoing state of disturbance of the fish community of Lake Orta should be taken into account when setting goals and targets for fish community restoration in the lake.

\section{DISCUSSION}

As in the majority of the Italian lakes, the native fish assemblage of Lake Orta was influenced by a complex set of geological, climatological and limnological variables. Indeed, although Alpine barriers and glaciation events likely determined species richness, species that overcame such factors faced various abiotic and biotic constraints and opportunities that modulated the fish assemblage (Griffiths, 2006; Gandolfi et al., 1991). Beginning in the $19^{\text {th }}$ century the fish communities of alpine Italian lakes faced significantly more human interventions. This is particularly true for lakes of the Po River basin which experienced introductions of salmonids, coregonids and centrarchids between 1850 and 1930. As a result, fish assemblages were quite homogeneous, with only the lake depth limiting the presence of specific functional groups, such as sensitive cold water species like salmonids and coregonids. Hence, the Lake Orta fish community was very similar to those of the other deep subalpine lakes of the Po River Basin (Volta et al., 2011b) including littoral, sublittoral and pelagic species, as well as partially or fully migratory ones (Tab. 1).

The pollution of the lake changed everything, with marked damage beginning in the 1930s. Mechanisms of fish impairment were manifold. Initially, metal toxicity damaged both phyto- and zooplankton, and fish were affected indirectly through a lack of food (Monti, 1930; Bonacina, 2001). This mechanism was particularly evi-
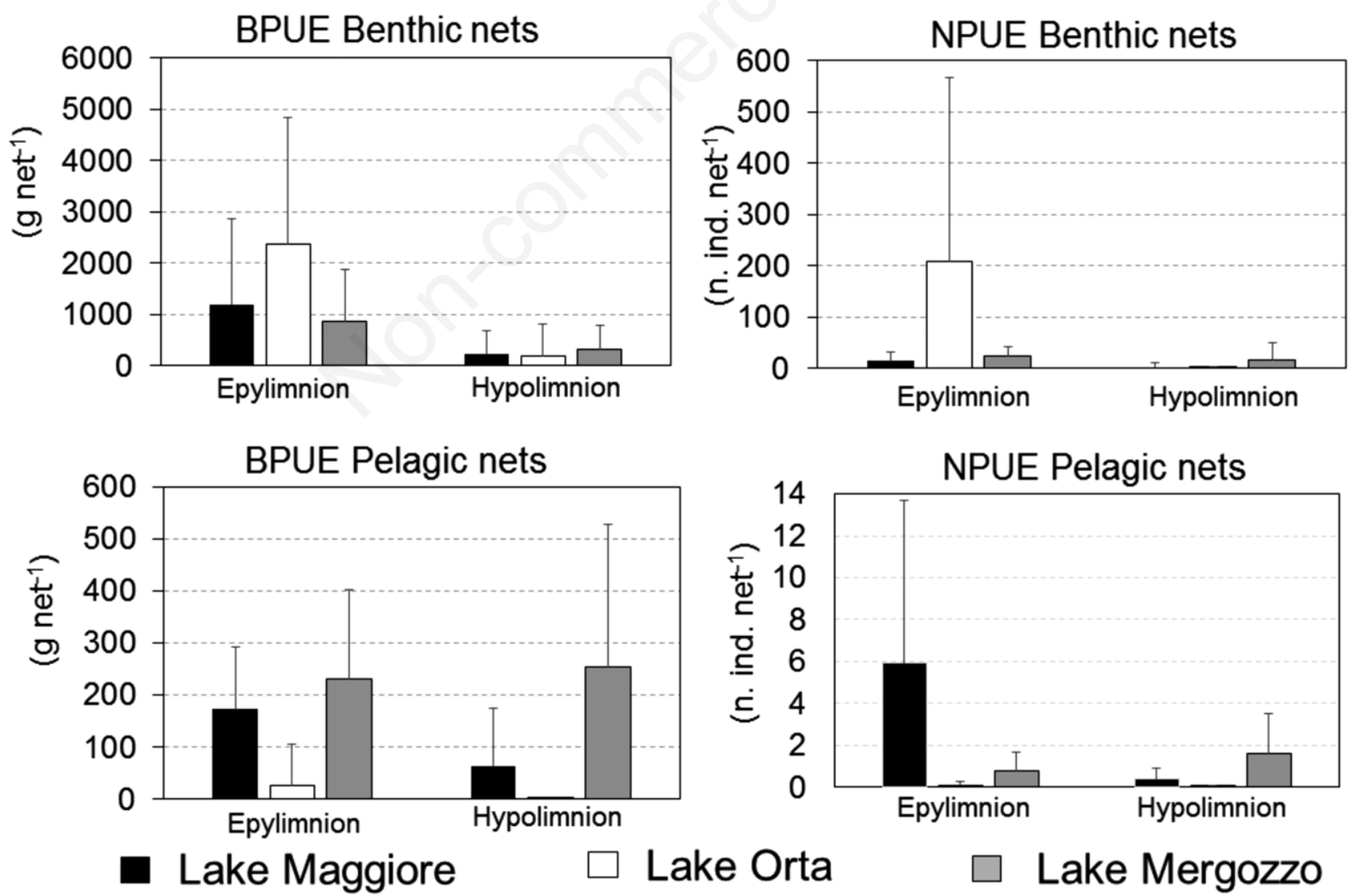

Fig. 1. Average BPUE $\left(\mathrm{g} \mathrm{net}^{-1}\right)$ and NPUE $\left(\mathrm{n}\right.$. ind. net ${ }^{-1}$ ) of the nets set in the epilimnion and hypolimnion of Lake Maggiore, Lake Orta and Lake Mergozzo. Error bars are Standard Deviation. 
dent in open waters, with pelagic zooplanktivores such as shad, whitefish, char and bleak, the first to be affected. Sensitive deep water species such as burbot and bullhead were also affected by hypolimnetic oxygen depletion attributable to ammonium oxidation. Finally, fish were directly affected by water acidification, mainly via impaired reproduction, and by heavy metals whose bioavailability and thus toxicity was exacerbated in the lake's acid waters (Giussani, 1990).

Littoral fish species, with more abundant and diverse food resources than pelagic fish, were a bit more resistant to pollution, although they may well have had to forage in limited, less polluted areas such as the mouths of inlets. Among the littoral species, only the perch likely maintained a self-sustaining population (Giussani, 1990). This is perhaps not surprising as perch are quite acid tolerant (Johansson and Millbrink, 1976), and have very plastic diets, undergoing ontogenetic diet shifts during its life (Craig, 2000; Persson et al., 2000). For instance, Giussani (1990) reported finding 25 perch of different sizes in the lake in 1987 with stomach contents comprised only of insect larvae (mainly Ephemeroptera), probably the only food available at that time. Despite their tolerance, the perch were limited to very small areas in the lake, mainly those close to inlet mouths and the northern part of the lake where the lake water was likely less contaminated. Still, Giussani (1990) found two and three year old perch together with young of the year and a few very old individuals $(>7 \mathrm{y})$ indicating high instability of the recruitment processes. Habitat acidification indeed does impair reproduction of many fish species (Lee and Gerking, 1980; Lee et al., 1983). As for many other acidified and metal-contaminated lakes in Canada (Wales and Begs, 1986; Gunn et al., 1988) or Scandinavia (Hesthagen et al., 1993; Rask et al., 1995) the most tolerant and resilient species was perch.

We hypothesized that because of the severity of past pollution and interruption of primary migratory routes, the present fish community would be comprised only of the species that have been recently reintroduced, and those few pollution-tolerant species that survived that lake's contaminated past. Consistent with our hypothesis, the number of species increased from only 3 in 1994 to 18 in 2014. Hence, in terms of fish diversity, the lake improved considerably over this twenty year period. Fish introductions carried out by the local fishing authorities soon after the liming likely provide a partial explanation. However, while the number of species is similar to that we have documented prior to pollution, the species composition remains different. For instance, shad, whitefish, arctic charr and burbot are still absent. This suggests that more must be done in order to rehabilitate either the native lake fish community, or at least a fish community more similar to one predating the period of pollution.
Our nets produced catches dominated by native species, which formed $95 \%$ of the numerical catch and $79 \%$ of the catch by weight. However, non-native species, mainly roach, were very abundant in the littoral electro-fishing records. There is no official record of roach introduction in Lake Orta; suggesting the most likely source as bait fish release, or their inclusion among those juvenile fish introduced soon after the liming. The presence of such high densities of roach is somewhat alarming, perhaps indicating an ongoing colonization process, which previously occurred in the neighbouring Lake Maggiore (Volta and Jepsen, 2008) and Lake Mergozzo (Volta et al., 2011a).

The fish community of Lake Orta has not as yet been restored. Some important functional categories of fish are still missing. The littoral community has largely recovered, now including both prey and predators, albeit with some shift in composition of prey species. Indeed, compared to historical data and to the other neighbouring lakes of same typology (Tab. 3), Lake Orta is still lacking cold water species such as coregonids, burbot, char and bullhead, which usually inhabit hypolimnetic waters. However, while we did find some perch, rudd and roach in our pelagic nets, we found no truly open water zooplanktivorous species such as shad and whitefish, in the lake. There may be many reasons for the continued absence of these species. However, we suspect the main reason is that fish introductions have targeted species of interest to anglers, rather than species which were historically present. The adoption of a more comprehensive ecosystem goal was not the restoration target. Only arctic charr of the missing species was reintroduced at the end of the 1990s, and this introduction was not successful. At that time the lake was likely not yet suitable for the sensitive arctic charr, as the average oxygen concentration in the hypolimnion was ca. $5 \mathrm{mg} \mathrm{L}^{-1}$ (Rogora et al., 2016).

Finally, native migratory species are still missing from the lake's fish assemblage. Marble trout and eel, for instance, were neither captured in the lake nor upstream of the weirs in the outlet River Strona (Volta, unpublished data). They were found in the river downstream of the last weir, proving that the River Strona could provide a suitable recolonization pathway for the lake, if the weirs were not an impassable obstacle to migrations. In contrast, potentially migrant brown trout were present in the lake and were captured in our nets. Brown trout juveniles are stocked every year into Lake Orta and its tributaries. Anglers have reported rare cases of spawning migration through the inlets in December and January, but no information is yet available about natural processes of recruitment.

In summary, the Lake Orta fish community cannot as yet be considered rehabilitated, because many species of the pristine fish community that preceded pollution are still absent. For this reason, our third objective was to consider what steps could next be taken to foster the restora- 
tion of Lake Orta's fish community. What should the priorities be in order to maximize benefit and minimize resource expenditure? We suggest the first step should be to categorize each fish species according to its value or importance, next to categorize the type of restorative intervention each species would require, then finally to judge the feasibility as well as probability of success of the intervention for each species, using a preliminary scientific assessment.

Following this evaluation, three missing fish species were classified at top priority for intervention: the shad, the whitefish and the marble trout (Tab. 4). The interventions aiming at restoring these species are different in terms of typology and resources needed. Indeed, whilst shad and whitefish are typically lacustrine species, and introductions of larvae or fry may be sufficient in presence of a suitable environment, the marble trout is a migratory species, thus interventions to rehabilitate its population must consider first of all the migratory routes and only later the lake itself.
The introduction of whitefish larvae has been a common practice in lakes of the boreal hemisphere since the end of 1800s (Svardson 1951; Berg and Grimaldi 1965; Iilmast and Sterligova, 2006; Winfield et al., 2013). If the environment is suitable in terms of physical and chemical characteristics (i.e., hypolimnion with oxygen concentration above $5 \mathrm{mg} \mathrm{L}^{-1}$ ) and adequate pelagic food resources (zooplankton including copepods and cladocerans), these introductions may be very successful in a short period of time (Berg and Grimaldi, 1965). At present, the limnological characteristics and the pelagic fauna of Lake Orta seem suitable for the reintroduction of European whitefish. Oxygen concentration in the hypolimnion while low during the period of ammonia pollution is once again high (Rogora et al., this issue) and pelagic copepods and daphnids are present (Piscia et al., this issue). Some problem could arise however because of the low food availability. Lake Orta is oligotrophic and the plankton concentrations are quite low and of low diversity. This may result in high mortality among the young fish larvae. To overcome this

Tab. 3. Composition of the present fish assemblages of Lake Orta, Lake Mergozzo and Lake Maggiore.

\begin{tabular}{|c|c|c|c|c|}
\hline Fish species & Habitat preference & Lake Orta & Lake Mergozzo & Lake Maggiore \\
\hline Bleak (Alburnus alburnus alborella) ${ }^{*}$ & OW & $\mathrm{X}$ & $\mathrm{X}$ & $\mathrm{X}$ \\
\hline Landlocked shad (Alosa fallax lacustris) ${ }^{*}$ & OW & - & $\mathrm{X}$ & $\mathrm{X}$ \\
\hline European whitefish (Coregonus lavaretus) & OW & - & $\mathrm{X}$ & $\mathrm{X}$ \\
\hline Bullhead (Cottus gobio) & SUB & - & $\mathrm{X}$ & $\mathrm{X}$ \\
\hline Burbot (Lota lota) & SUB & - & $\mathrm{X}$ & $\mathrm{X}$ \\
\hline Char (Salvelinus alpinus) & SUB & - & $\mathrm{X}$ & $\mathrm{X}$ \\
\hline Blenny (Salaria fluviatilis) & LIT & $\mathrm{X}$ & $\mathrm{X}$ & $\mathrm{X}$ \\
\hline Carp (Cyprinus carpio) & LIT & $\mathrm{X}$ & $\mathrm{X}$ & $\mathrm{X}$ \\
\hline Chub (Squalius cephalus) & LIT & $\mathrm{X}$ & $\mathrm{X}$ & $\mathrm{X}$ \\
\hline Crucian carp (Carassius carassius) & LIT & $\mathrm{X}$ & - & $\mathrm{X}$ \\
\hline Italian roach "triotto" (Rutilus erythrophthalmus) ${ }^{*}$ & LIT & - & $\mathrm{X}$ & $\mathrm{X}$ \\
\hline Largemouth bass (Micropterus salmoides) & LIT & $\mathrm{X}$ & $\mathrm{X}$ & $\mathrm{X}$ \\
\hline Padanian goby (Padogobius martensii) ${ }^{*}$ & LIT & $\mathrm{X}$ & $\mathrm{X}$ & $\mathrm{X}$ \\
\hline Perch (Perca fluviatilis) & LIT & $\mathrm{X}$ & $\mathrm{X}$ & $\mathrm{X}$ \\
\hline Pike (Esox lucius) & LIT & $\mathrm{X}$ & $\mathrm{X}$ & $\mathrm{X}$ \\
\hline Pikeperch (Sander lucioperca) & LIT & $\mathrm{X}$ & $\mathrm{X}$ & $\mathrm{X}$ \\
\hline Pumpkinseed (Lepomis gibbosus) & LIT & $\mathrm{X}$ & $\mathrm{X}$ & $\mathrm{X}$ \\
\hline Roach (Rutilus rutilus) & LIT & $\mathrm{X}$ & $\mathrm{X}$ & $\mathrm{X}$ \\
\hline Rudd (Scardinius erythrophthalmus) & LIT & $\mathrm{X}$ & $X$ & $\mathrm{X}$ \\
\hline Tench (Tinca tinca) & LIT & $\mathrm{X}$ & $\mathrm{X}$ & $\mathrm{X}$ \\
\hline Ruffe (Gymnocephalus cernuus) & LIT & - & $\mathrm{X}$ & $\mathrm{X}$ \\
\hline Spined loach (Cobitis taenia) & LIT & $\mathrm{X}$ & $\mathrm{X}$ & $\mathrm{X}$ \\
\hline Welsh catfish (Silurus glanis) & LIT & - & - & $\mathrm{X}$ \\
\hline Padanian barbel (Barbus plebejus) ${ }^{*}$ & POT & - & - & $\mathrm{X}$ \\
\hline Minnow (Phoxinus phoxinus) & POT & - & $\mathrm{X}$ & $\mathrm{X}$ \\
\hline "Pigo" (Rutilus pigus) $)^{*}$ & POT & - & - & $\mathrm{X}$ \\
\hline Riffle dace (Telestes souffia) & POT & $\mathrm{X}$ & $\mathrm{X}$ & $\mathrm{X}$ \\
\hline Gudgeon (Gobio gobio) & POT & $\mathrm{X}$ & $\mathrm{X}$ & $\mathrm{X}$ \\
\hline "Savetta" (Chondrostoma soetta) ${ }^{*}$ & POT & - & - & $\mathrm{X}$ \\
\hline Brown trout (Salmo trutta trutta) & MIG & $\mathrm{X}$ & $\mathrm{X}$ & $\mathrm{X}$ \\
\hline Marble trout (Salmo trutta marmoratus) ${ }^{*}$ & MIG & - & - & $\mathrm{X}$ \\
\hline Eel (Anguilla anguilla) & MIG & - & $\mathrm{X}$ & $\mathrm{X}$ \\
\hline Twaite shad (Alosa fallax) & MIG & - & - & - \\
\hline
\end{tabular}

*Endemisms; OW, open waters; SUB, sublittoral waters; LIT, littoral waters; RHE, rheophilic; MIG, migratory. 
problem, two different approaches could be used (EIFAC, 1994). First, the number of yolk sac larvae stocked every year could be very high (approximately around 15 million). This approach would require us to catch a high number of spawners (at least 600 females of $1 \mathrm{~kg}$ each per year) which could produce ca 20 million of eggs (assuming a hatching success of $75 \%$ ). As an alternative, larvae could be reared to a size of $5-6 \mathrm{~cm}$ in illuminated cages in more eutrophic lakes or ponds and then transported in Lake Orta. This procedure could help overcome the high mortality in the first 30-50 days of life but needs rearing infrastructure, and, a nearby nutrient-rich lake close to the hatchery, a potential problem in the case of Lake Orta.

While the artificial propagation of coregonids has been common in Europe since the 1850s, it is apparently not common for landlocked shad, as this species is present only in north Italian lakes and was not supported by stocking practice in the past. However, artificial propagation of shad species is still common in the USA (http://www.dgif.virginia.gov/fishing/shad-restoration) and, has been a part of conservation programs of large rivers in Central Europe (http://www.lanuv.nrw.de/alosa-alosa/index.html). Similar to European whitefish, the easiest method is to capture many spawners, breed them in a hatchery, and then release young fry as soon they have absorbed the yolk sac. All limnological and biological characteristics of Lake Orta now appear to be suitable for a shad re-introduction. This species is zooplanktivorous (Berg and Grimaldi, 1966a), and inhabits mainly surface waters during summer and autumn. However, shad can compete with whitefish, at least in the spring and winter when they share the same depth strata (Berg and Grimaldi, 1966b). For this reason we propose delays in shad introduction to the lake. This delay could be used productively to develop and test hatchery procedures in order to maintain a year round captive broodstock of shad that could be used for future introductions, obviating the need to take the spawners from Lake Maggiore every year.

Restoring water connectivity and ecological corridors is a primary objective of many current environmental laws and management guidelines across Europe. However, the funds required to restore corridors are often very high. Removing weirs and dams, restoring natural water courses and building fish ladders and passages require significant funds, making the restoration of the connectivity along the River Strona very expensive. Four weirs are present along the river, and while their removal would improve the connectivity among Lake Orta and the River Po Basin, the cost would be at least one or two orders of magnitude higher than that necessary for the reintroduction of the whitefish and the shad in the lake. Such cost differentials must be taken into account by lake managers as they develop their plans to restore the fish in Lake Orta.

\section{CONCLUSIONS}

Almost all previous studies of acidified lakes have been of northern, oligotrophic waters with simple fish communities dominated by salmonids such as brown trout that have been impacted by acid rain. The present study on Lake Orta with its much more complex fish community makes a contrasting contribution.

Although the quality of information assembled has gear biases, the combination of different sampling techniques enabled us to obtain a good dataset which can be utilized as reference point in order to assess future changes of the fish community in the lake. The littoral fish assemblage of the lake has recovered, reaching a status approximating the pre-pollution period. However, the pelagic, deep water and migratory fish fauna still require important interventions. The conservation, ecological and

Tab. 4. Categorization of the overall value of the missing fish species in Lake Orta using four criteria.

\begin{tabular}{|c|c|c|c|c|}
\hline Fish species & EU Interest & WFD 2000/60/EC & Fishery & Angling \\
\hline Landlocked shad (Alosa fallax lacustris) ${ }^{*}$ & 1 & 1 & 1 & 0 \\
\hline European whitefish (Coregonus lavaretus) & 0 & 1 & 1 & 1 \\
\hline Marble trout $(\text { Salmo marmoratus })^{*}$ & 1 & 1 & 0 & 1 \\
\hline Burbot (Lota lota) & 0 & 1 & 1 & 0 \\
\hline Char (Salvelinus alpinus) & 0 & 0 & 1 & 1 \\
\hline Eel (Anguilla anguilla) & 1 & 0 & 1 & 0 \\
\hline Twaite shad (Alosa fallax) & 1 & 1 & 0 & 0 \\
\hline Italian roach triotto (Rutilus aula) ${ }^{*}$ & 1 & 1 & 0 & 0 \\
\hline Italian nasus (Chondrostoma soetta) $^{*}$ & 1 & 0 & 0 & 0 \\
\hline Bullhead (Cottus gobio) & 1 & 0 & 0 & 0 \\
\hline Padanian barbel (Barbus plebejus) $^{*}$ & 1 & 0 & 0 & 0 \\
\hline Minnow (Phoxinus phoxinus) & 0 & 0 & 0 & 0 \\
\hline Pigo (Rutilus pigus) ${ }^{*}$ & 1 & 0 & 0 & 0 \\
\hline
\end{tabular}

WFD 2000/60/EC: European Council, 2000; *endemisms; 1, recognized value; 0, no value. 
fishing values of the missing fish species indicate the restoration of shad and European whitefish should receive highest priority. Nonetheless, we remain concerned that the present condition of the fish assemblage in Lake Orta is unstable, and requires strict management by local fishing authorities. For instance, stocking of predators such as trout Salmo trutta for angling purposes should be interrupted when artificial propagation of whitefish and shad is initiated in order to avoid excessive predation on the reintroduced young fish. Also, the monitoring of the chemical and ecological status of the lake must continue in order to provide those data needed to evaluate the success of fish management and restoration in the lake over the next several years.

\section{REFERENCES}

Appelberg M, Berger HM, Hesthagen T, Kleiven E, Kurkilahti M, Raitaniemi J, Rask M, 1995. Development and intercalibration of methods in Nordic freshwater fish monitoring. Water Air Soil Poll. 85:401-406.

Baldi E, 1949. [Il Lago d'Orta, suo declino biologico e condizioni attuali].[Article in Italian]. Mem. Ist. Ital. Idrobiol. 5:145-188.

Berg A, Grimaldi E, 1965. [Biologia delle due forme di coregone (Coregonus sp.) del Lago Maggiore].[Article in Italian]. Mem. IstItal. Idrobiol. 20: 41- 83.

Berg A, Grimaldi E, 1966a. [Biologia dell'agone (Alosa ficta lacustris) del Lago Maggiore].[Article in Italian]. Mem. Ist. Ital. Idrobiol. 20: 41-83.

Berg A, Grimaldi E, 1966b. Ecological relationships between planktophagic fish species in the Lago Maggiore. Verh. Internat. Limnol. 60:1-52.

Bonacina C, 2001. Has Lake Orta completely recovered from its heavy polluted condition? A seventy years long history. In: C. Bonacina and R. Baudo (eds.), Lake Orta: a case study. J. Limnol. 60:285-287.

Byström P, Persson L, Wahlström E, 1998. Competing predators and prey: juvenile bottlenecks in whole-lake experiments. Ecology 79:2153-2167.

Calderoni A, Mosello R, Ruggiu D, 1992. Sixty years of limnology on Lago d'Orta: a case history of recovery from heavy pollution. In: P. Guilizzoni, G. Tartari and G. Giussani (eds.), Limnology in Italy. Mem. Ist. Ital. Idrobiol. 50: 201-224.

Calderoni A, Tartari GA, 2001. Evolution of the water chemistry of Lake Orta after liming. In: C. Bonacina and R. Baudo (eds.), Lake Orta: a case study. J. Limnol. 60:69-78.

CEN, 2005. Water quality - Sampling of fish with multi-mesh gillnets (English version prEN 14757:2013). European Committee for Standardization, Brussels.

Copp GH, Garner P, 1995. Evaluating the microhabitat use of freshwater fish larvae and juveniles with point abundance sampling by electrofishing. Folia Zool. 44:145-158.

Craig J, 2000. Percid fishes. Systematics, ecology and exploitation. Blackwell Science, Oxford: 370 pp.

De Agostini G, 1927. [Flora, fauna e pesca del Lago d'Orta].[Article in Italian]. Cusiana 6:121-124.

European Council, 1992. Directive 92/43/EEC on the conserva- tion of natural habitats and of wild fauna and flora. Official Journal, L206, pp. 7-50.

European Council, 2000. Directive 2000/60/EC of the European Parliament and of the Council of 23 October 2000 establishing a framework for Community action in the field of water policy. Official Journal, L327, pp. 1-72.

European Inland Fisheries Advisory Commission, 1994. Guidelines for stocking coregonids. EIFAC Occasional Paper. No. 31. FAO, Rome: $18 \mathrm{pp}$.

Galloway JN, 2001. Acidification of the world: natural and anthropogenic. Water Air Soil Poll. 130:17-24.

Gandolfi G, Zerunian S, Torricelli P, Marconato A, 1991. [I pesci delle acque interne italiane].[Book in Italian]. Ist. Poligrafico e Zecca dello Stato, Roma: 617 pp.

Gassner H, Achleitner D, Luger M, Ritterbush D, Schubert M, Volta P, 2014. Alpine lake fish fauna ecological assessment methods. In: S. Poikane (ed.), Water Framework Directive Intercalibration Technical Report. JRC Technical Reports: 68 pp.

Giussani G, 1990. [La fauna ittica del Lago d'Orta]. In: C. Bonacina, A. Calderoni and R. de Bernardi (eds.), [Ricerche limnologiche sul Lago d'Orta finalizzate al suo risanamento].[Article in Italian]. Doc. Ist. Ital. Idrobiol. 28:109-115.

Griffiths D, 2006. Pattern and processes in the ecological biogeography of European freshwater fish. J. Anim. Ecol. 75:734-751.

Gunn JM, Mc Murtry MJ, Casselmann JM, Keller W, Powell MJ, 1988. Changes in the fish community of a limed lake near Sudbury, Ontario. Effect of chemical neutralization or reduced atmospheric deposition of acids ? Water Air Soil Poll. 41:113-136.

Henriksen A, Lien L, Rossleand BO, Traaen TS, Sevaldrud IS, 1989. Lake acidification in Norway: present and predicted fish status. Ambio 18:314-321.

Hesthagen T, Rosseland BO, Berger HM, Larsen BM, 1993. Fish community status in Norwegian lakes in relation to acidification: a comparison between interviews and actual catches by test-fishing. Nord. J. Freshwater Res. 68:34-41.

Hutchings JA, Festa-Bianchet M, 2009. Canadian species at risk (2006-2008), with a particular emphasis on fishes. Env. Rev. 17:53-65.

Ilmast NV, Sterligova OP, 2006. Results of the introduction of Coregonids to Lake Vashozero. J. Ichthyol. 46:156-161.

ISPRA, 2014. [Metodi biologici per le acque superficiali interne].[Book in Italian]. Manuali e Linee Guida 111, ISPRA, Roma.

Johansson N, Milbrink G, 1976. Some effects of acidified water on the early development of roach (Rutilus rutilus L.) and Perch (Perca fluviatilis L.). Water Res. Bull. 12:39-48.

Lee RL, Gerking SD. 1980. Sensitivity of fish eggs to acid stress. Wat. Res. 14:1679-1681.

Lee RL, Gerking SD, Jezierka B, 1983. Electrolyte balance and energy mobilization in acid stresses raimbow trout, Salmo gairdneri, and their relation to reproductive success. Environ. Biol. Fish. 8:115-123.

Likens E, Wright RF, Galloway JN, Butler TJ, 1979. Acid rain. Sci. Am. 241:43-51.

Monti R, 1930. [La graduale estinzione della vita nel limnobio del Lago d'Orta].[Article in Italian]. Rend. Ist. Lomb. Sc. Lett. 63:3-22.

Olson MH, 1996. Predator-prey interactions in size-structured 
fish communities, implications of prey growth. Oecologia 108:757-763.

Pain DJ, Sanchez A, Meharg AA, 1998. The Donana ecological disaster: contamination of a world heritage estuarine marsh ecosystem with acidified pyrite mine waste. Sci. Tot. Environ. 222:45-54.

Pavesi P, 1896. [La distribuzione dei pesci in Lombardia].[Book in Italian]. Società Lombarda per la pesca e l'acquicoltura: 40 pp.

Persson L, Byström P, Wahlström E, 2000. Cannibalism and competition in Eurasian perch: population dynamics of an ontogenetic omnivore. Ecology 81:1058-1071.

Persson L, De Roos AM, Byström P, 2007. State-dependent invasion windows for prey in size-structured predator-prey systems: whole lake experiments. J. Anim. Ecol. 76:94-104.

Piscia R, Yan N, Manca M, (2015). Mechanisms underlying recovery of zooplankton in Lake Orta after liming. J. Limnol. (in press).

Rusconi A, 1887. [Guida del Lago d'Orta e sua riviera].[Book in Italian]. F.1li Miglio, Novara: 282 pp.

Rask M, Mannio J, Forsius M, Posch M, Vuorinen PJ, 1995. How many fish populations in Finland are affected by acid precipitation? Environ. Biol. Fish. 42:51-63

Rogora M, Kamburska L, Mosello R, Tartari G, 2016. Lake Orta chemical status 25 years after liming: problems solved and emerging critical issues. J. Limnol. 75(s2):93-106.

Schuurkes JAAR, Mosello R, 1988. The role of external ammonium inputs in freshwater acidification. Schweiz. Z. Hydrol. 50:71-86.

Smejkal M, Ricard D, Prchalová M, Ríha M, Muška M, Blabolil P, Čech M, Vašek M, Jůza T, Monteoliva Herreras A, Encina L, Peterka J, Kubečka J. 2015. Biomass and abundance biases in European atandard gillnet sampling. PLoS One 10:e122437.
Svardson G, 1951. The coregonid problem. III. Whitefish from the Baltic successfully introduced into freshwaters in the north of Sweden. Rep. Inst. Freshwat. Res. Drottningholm 32:79-125.

Tonolli V, 1957. [La situazione attuale del Lago d'Orta e possibilità del suo recupero come ambiente di pesca].[Article in Italian]. Notiziario Economico 5:17-24.

Van de Wolfshaar K, de Roos AM, Persson L, 2006. Size-dependent interactions inhibit coexistence in intraguild predation systems with life-history omnivory. Am. Nat. 168: 62-75.

Volta P, Jepsen N, 2008. The recent invasion of Rutilus rutilus (L.) (Pisces: Cyprinidae) in a large South-Alpine lake: Lago Maggiore. J. Limnol. 67:163-170.

Volta P, Sala P, Cerutti I, 2011. [Aggiornamento delle conoscenze relative alla fauna ittica del Lago di Mergozzo (VB) con brevi note gestionali].[Report in Italian]. Report CNR-ISE 01.11: 14 pp.

Volta P, Oggioni A, Bettinetti R, Jeppesen E, 2011. Assessing lake typologies and indicator fish species for Italian natural lakes using past fish richness and assemblages. Hydrobiologia 671:227-240.

Wales DL, Begs GL, 1986. Fish species distribution in relation to lake acidity in Ontario. Water Air Soil Poll. 30:601-609.

Winfield IJ, Nelson JS, 1991. Cyprinid fishes: systematics, biology and exploitation. Chapman \& Hall, London: 668 pp.

Zacchera L, 1948. [Principali laghi d'Italia, loro pescosità e contributo all'economia nazionale].[Phd Thesis in Italian]. University of Milan Bocconi.

Zerunian S, 2004. [I pesci delle acque interne d'Italia].[Report in Italian]. Quaderni della Conservazione della Natura n. 20, Ministro dell'Ambiente, Istituto Nazionale Fauna Selvatica, Rome. 